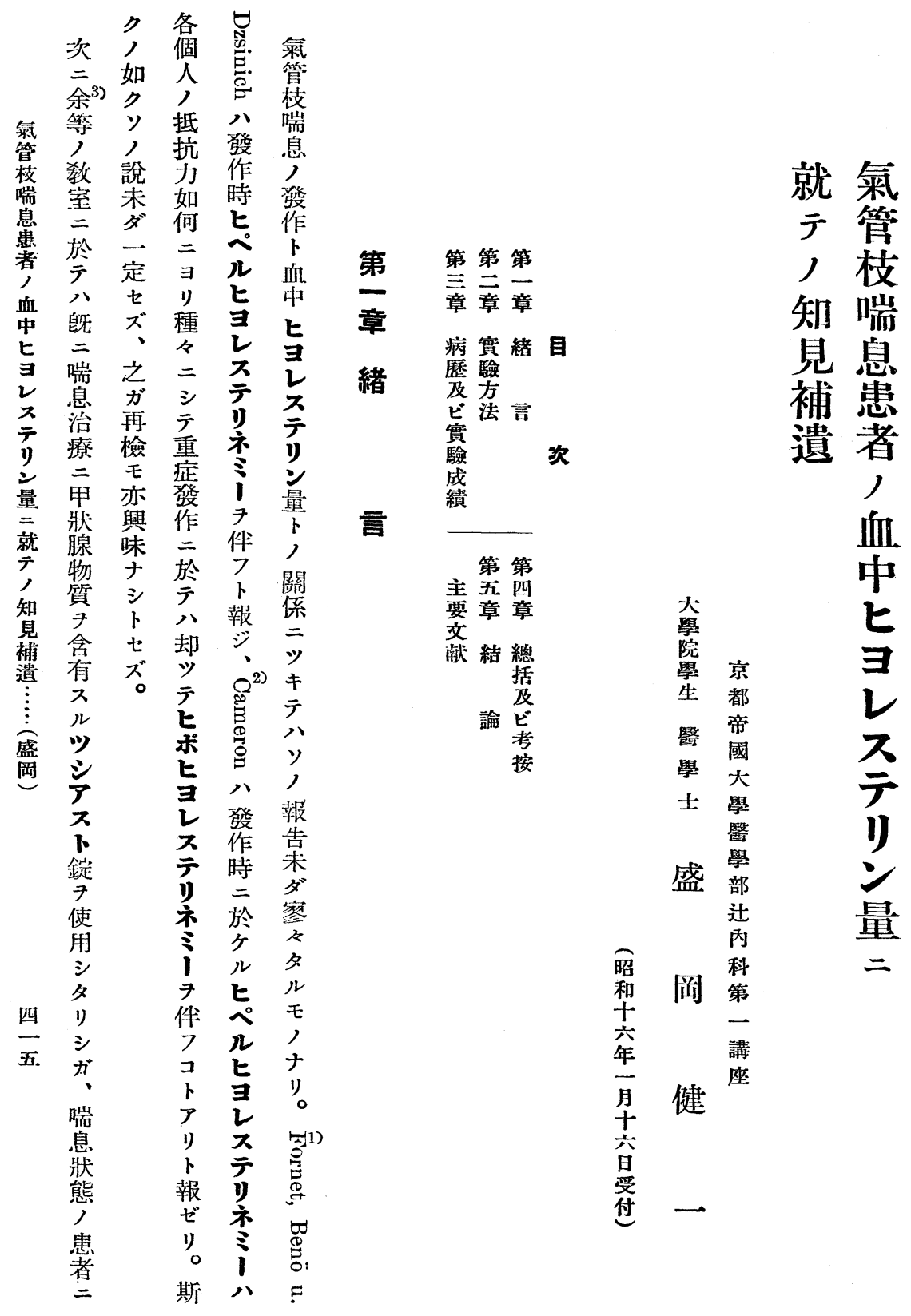




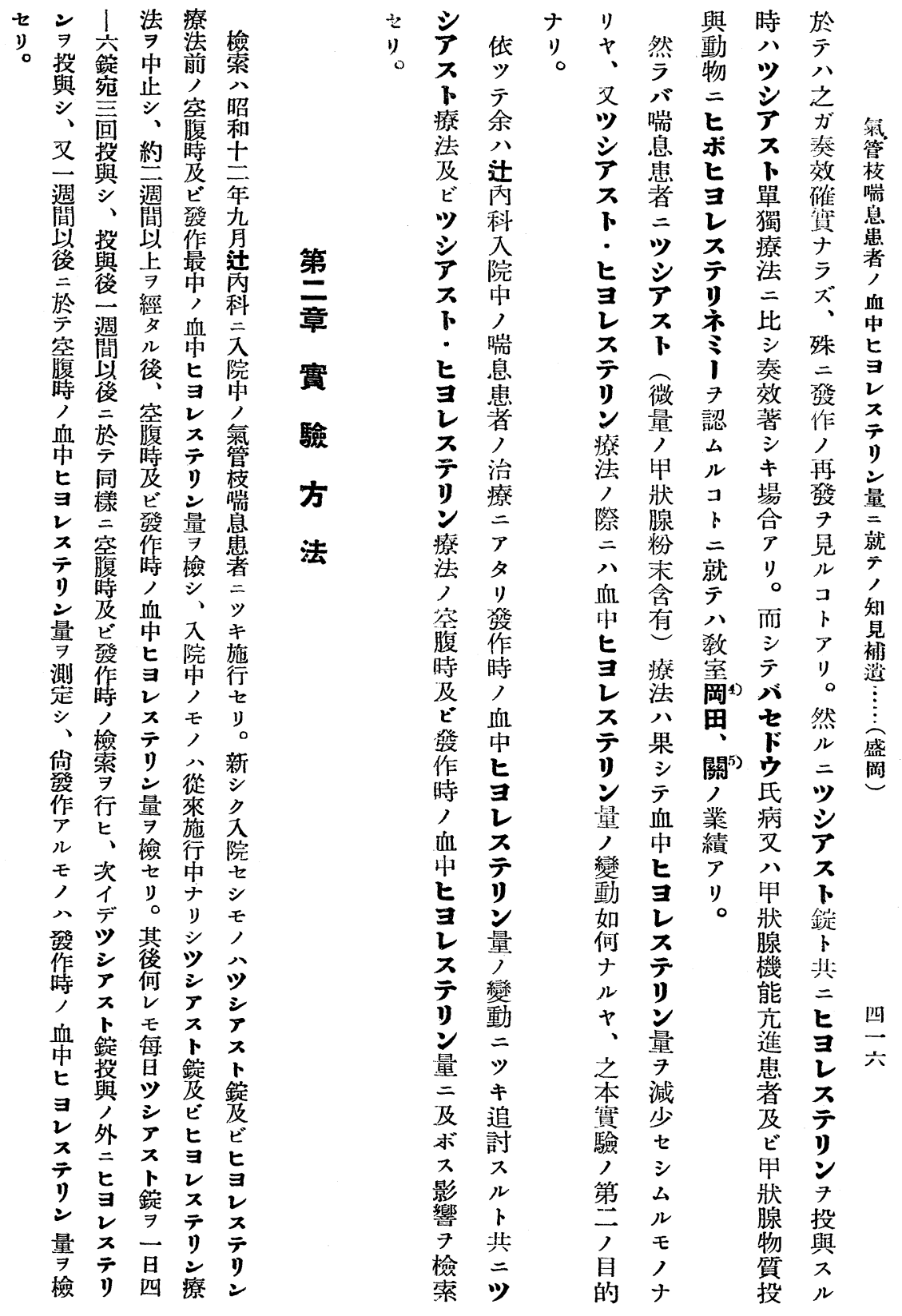


最十第此發吾是色

近歳忽, 登 \% 起百入照照第

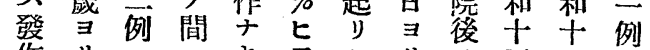

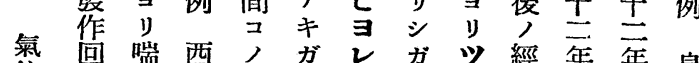

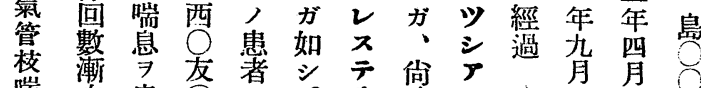

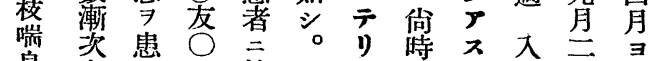

息多歬

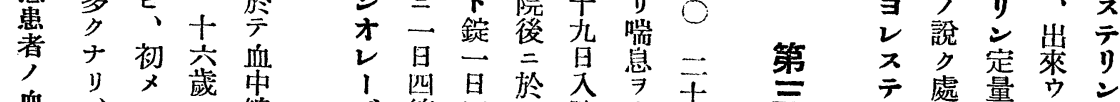

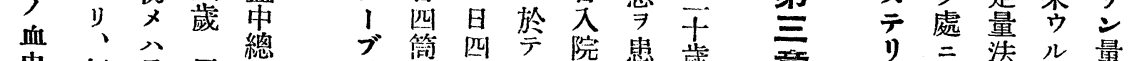

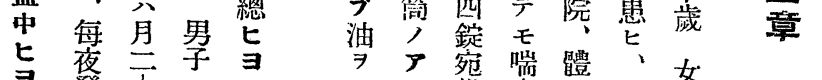

り $=$ 法 ル 量

亲從费限学

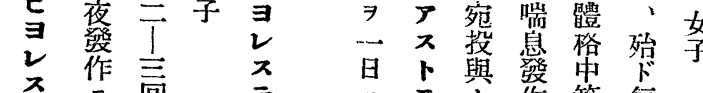

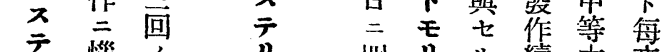

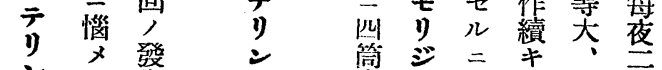

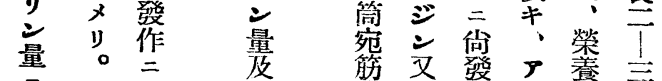

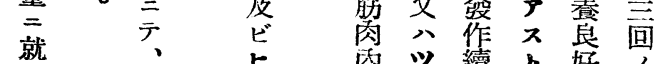

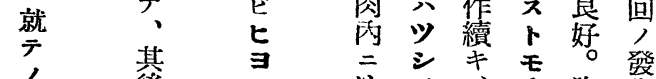

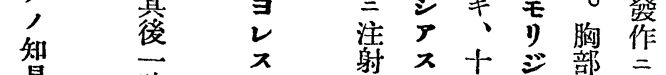

見補時

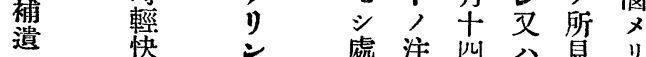

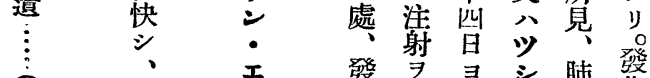

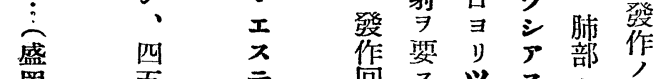

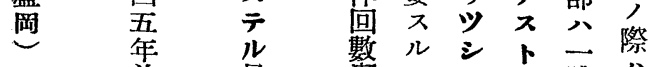

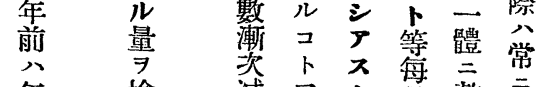

年檢 減劣占昌乾注

四 等 少 y。錠百性注

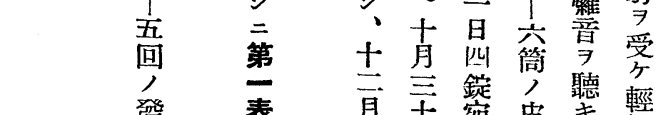

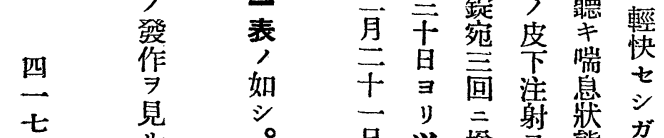

病学處奢午實

歴 \% 理 正 前驗

及 分密簡

ビ 割定量静 七中

實 才量脽质時患

驗㢳

成 ブ先燥於 シ

油寻梠宁、

示父注起食

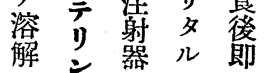

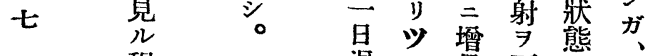

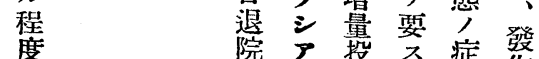

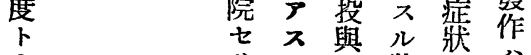

ナ リ リ せ 狀录寒

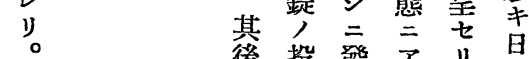

然 覞 與 作

外手十

筋 少

注量 行採 以

注 量 行 血 後

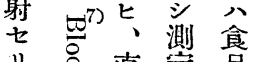

り气直定嵒

之心

詳壳, 取

細总全息禁

迁3)氐监禁

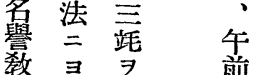

教 $\exists \quad \exists \quad$ 前

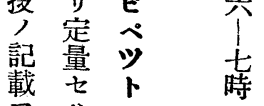

$\begin{array}{lll} & y & = \\ \text { リ } & \text { 間 }\end{array}$

旨正確於 


\begin{tabular}{|c|c|c|c|c|c|c|}
\hline 昭 & & & 第一表 & 鳥 & $\bigcirc$ 交 $\bigcirc$ & \\
\hline $\begin{array}{l}\text { 和 } \\
\text { 至 } \\
\text { 年 } \\
\text { 九 }\end{array}$ & 日 附 & $\begin{array}{l}\text { 總ヒヨ } \\
\text { レステ } \\
\text { リン量 } \\
(\mathrm{mg} / \mathrm{dl}) \\
\end{array}$ & $\begin{array}{l}\text { ヒョコス } \\
\text { デンエ } \\
\text { ステル量 } \\
(\mathrm{mg} / \mathrm{dl})\end{array}$ & 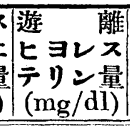 & 療 & $\begin{array}{l}\text { 發作 又 } \\
\text { 空腹時 / 別 }\end{array}$ \\
\hline 目 & 9 月 30 日 & 158.87 & 61.44 & 97.43 & & $\begin{array}{l}\text { 發作時 } \\
\text { (稍䱁) }\end{array}$ \\
\hline \pm & 10 月 3 日 & 150.15 & 65.90 & 84.25 & & 空腹時 \\
\hline 旦 & 10 月 6 日 & 165.95 & 66.69 & 99.26 & & $\begin{array}{l}\text { 發作時 } \\
\text { (稍重) }\end{array}$ \\
\hline 阮 & 10月 7 日 & 156.26 & 62.31 & 93.95 & & 空腹時 \\
\hline 長 & 10月13日 & 151.42 & 63.13 & 88.29 & $\begin{array}{l}\text { 10月7日 } 7 \text { 日ツシ } \\
\text { アスト1×IV.定 }\end{array}$ & 空腹時 \\
\hline $\begin{array}{l}\text { ル } \\
モ\end{array}$ & 10月19日 & 153.21 & 66.96 & 86.25 & $\begin{array}{l}\text { 10月14日 } 3 \text { アツシ } \\
\text { アスト } 3 \times I V . \text { 定 }\end{array}$ & $\begin{array}{l}\text { 發作時 } \\
\text { (稍重) }\end{array}$ \\
\hline 骨 & 10 月 20 日 & 145.56 & 66.45 & 79.11 & 同 上 & 埮腹時 \\
\hline 纖 & 10 月 30 日 & 138.57 & 62.89 & 75.68 & 同 & 空腹時 \\
\hline 䈢 & 11月 5 日 & 136.61 & 56.02 & 80.59 & $\begin{array}{l}\text { 同 } \\
10 \text { 月 } 30 \text { 日 } \\
\text { レスヒョ } \\
\text { ブ油 一シオン四筒 }\end{array}$ & $\begin{array}{l}\text { 發作時 } \\
\text { (稍輕) }\end{array}$ \\
\hline 条 & 11月 6 日 & 135.95 & 54.42 & 81.53 & 同 上 & 空腹時 \\
\hline 两 & & & 第二表 & 西 0 & 友 $\bigcirc$ & \\
\hline 胴 & 日 附 & \begin{tabular}{|c|} 
總ヒョコ \\
レステ \\
リン量 \\
$(\mathrm{mg} / \mathrm{dl})$ \\
\end{tabular} & $\begin{array}{l}\text { ヒヨレス } \\
\text { テリンั } \\
\text { スデル量 } \\
(\mathrm{mg} / \mathrm{dl})\end{array}$ & 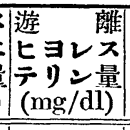 & 治 & $\begin{array}{l}\text { 發作又八 } \\
\text { 空腹時，别 }\end{array}$ \\
\hline 旨 & 9 月30日 & 160.59 & 80.58 & 79.99 & & 空腹時 \\
\hline $\begin{array}{l}\text { 骨 } \\
\text { 公 }\end{array}$ & 10月 3 日 & 149.49 & 97.52 & 51.97 & & $\begin{array}{l}\text { 發作時 } \\
\text { (稍重) }\end{array}$ \\
\hline 先 & 10 月 6 日 & 158.04 & 97.80 & 60.24 & & 空腹時 \\
\hline $\begin{array}{l}\text { 的 } \\
=\end{array}$ & 10 月 14 日 & 136.59 & 95.22 & 41.37 & $\begin{array}{l}\text { 10月6日 } 6 \text { 日リツシ } \\
\text { アスト } 3 \times \text { IV 定 }\end{array}$ & $\begin{array}{c}\text { 發作時 } \\
\text { (重) }\end{array}$ \\
\hline 渏 & 10月16日 & 150.97 & 98.04 & 52.93 & 同 上 & 空腹時 \\
\hline $\begin{array}{l}\bar{\gamma} \\
y \\
\circ \\
\text { 房 } \\
\text { 明 }\end{array}$ & 10 月 29 日 & 155.95 & 94.92 & 61.03 & $\begin{array}{l}\text { 同 } \\
10 \text { 月 } 20 \text { 日 } \\
\text { レ゙ヒョ } \\
\text { ブ油 } 1 \text { 日 } 6 \text { 筒宛 }\end{array}$ & $\begin{array}{l}\text { 發作時 } \\
\text { (私輕) }\end{array}$ \\
\hline 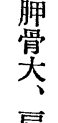 & 10月 31 日 & 155.13 & 85.47 & 69.66 & 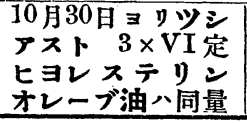 & 空腹時 \\
\hline
\end{tabular}




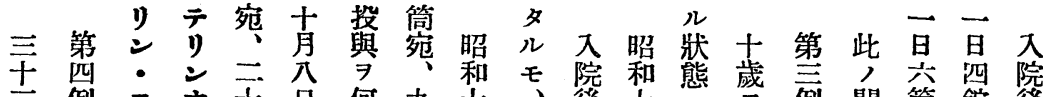

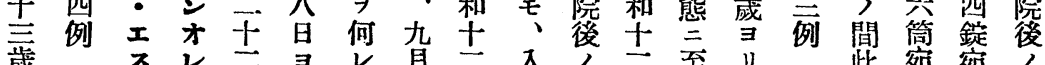

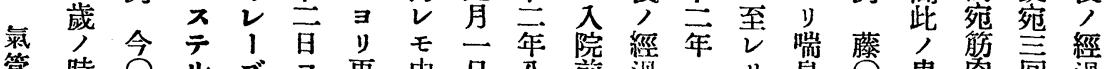

管時

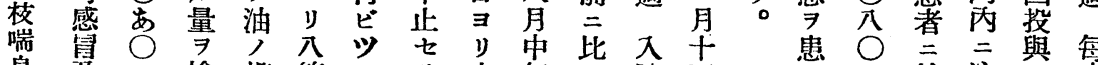

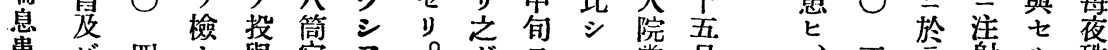

患ビ四七與宛

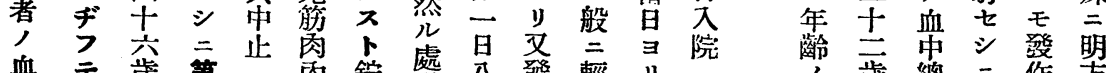

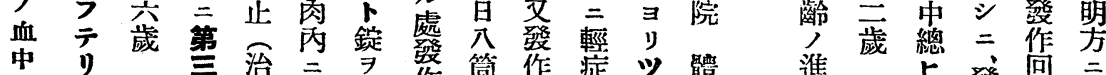

当

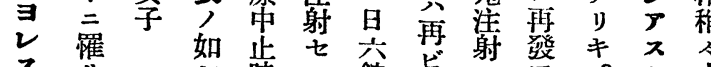

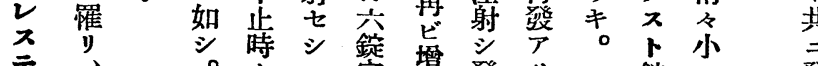

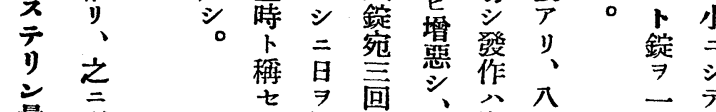

量引

就 續

当經投 與 漸 旦

テ キ

知息

見 息

科患

遺念

盛 其

岡年

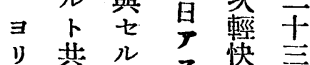

再三王沓向

度發著 モ 向录

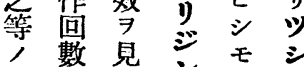

投數見妾文文

與少、文九

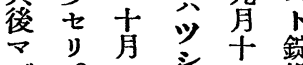

デ。 兵主五投

進

間, 此古

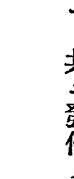

四 频

间患

卜

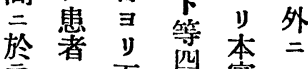

共

血

㭝麇

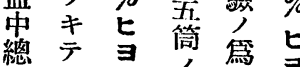

總テ茨当皮学寻

ス吾

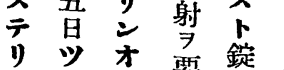

强

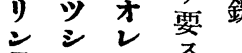

亲

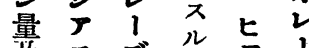

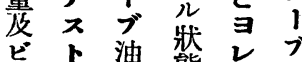

增

七 錠態

ヨ毞六 た テ

最

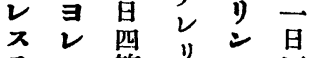

日 骨 頻

六錠 䋍

宛細

$\begin{array}{lll}\text { 回 } & \text { ソ } \\ \text { 投 モ } & \text { 强 }\end{array}$

與笪

り。佳增

入

院 胸

学所

筧

又

錠 息

錠 態

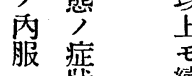

拘牀續

亏 旺 注

時 光射

及

發

作

再

發

見

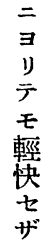

回 $\overrightarrow{\text { 日 作 }}$

發

最

テ

發

作

制

头

上

續

射
$=$
リ

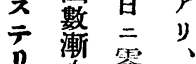

量减 零

量少自

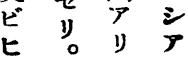

其品

後基市

テ 此旦 只

》治南

- 療搨

エ 續

ス 雳觉

テ シ シ シ

量發 作占店

檢全錠午

七沙鸷㴬

二退,

第立外要

表照吾 り

如士 七古

。年 v 六

士

月 》

七ั

退方豆

院 1 ス

当油錠 
苐三表 藤 $\bigcirc$ 八

\begin{tabular}{|c|c|c|c|c|c|}
\hline 日 附 & 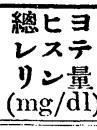 & 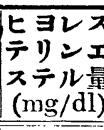 & 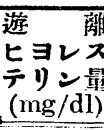 & 療 & $\begin{array}{l}\text { 發作 又八 } \\
\text { 空腹時ノ別 }\end{array}$ \\
\hline 9 月 30 日 & 152.91 & 87.33 & 65.58 & 治療中止 時 & 空腹時 \\
\hline 10月 3 日 & 168.39 & 95.10 & 73.29 & 同 & $\begin{array}{l}\text { 發作時 } \\
\text { (連) }\end{array}$ \\
\hline 10月 8 日 & 163.24 & 98.04 & 65.20 & 上 & $\begin{array}{l}\text { 發作時 } \\
\text { (稍重) }\end{array}$ \\
\hline 10月 8 日 & 156.05 & 98.04 & 58.01 & 同 & 空腹時 \\
\hline 10月 19 日 & 160.26 & 98.70 & 61.56 & $\begin{array}{l}\text { 10月8日ョリツシ } \\
\text { アト } 3 \times V I \text { V定 }\end{array}$ & $\begin{array}{l}\text { 發作時 } \\
\text { (重) }\end{array}$ \\
\hline 10 月 20 日 & 150.49 & 100.92 & 49.57 & 同 & 空腹時 \\
\hline 10 月 27 日 & 141.65 & 91.41 & 50.24 & 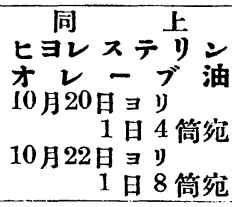 & $\begin{array}{l}\text { 發作時 } \\
\text { (稍輕) }\end{array}$ \\
\hline 10 月 29 日 & 144.93 & 93.87 & 51,06 & 同 & 空腹時 \\
\hline
\end{tabular}

第四表 今 $\bigcirc$ あ

\begin{tabular}{|c|c|c|c|c|c|c|}
\hline 日 附 & 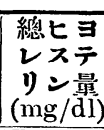 & 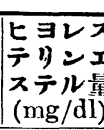 & 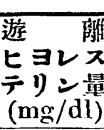 & 治 & 療 & 發 作 又一 \\
\hline 9 月 28 日 & 155.35 & 7407 & 81.28 & 治 療 中 & 止 時 & 㷊腹時 \\
\hline 10月 3 日 & 172.18 & 87.45 & 84.76 & 同 & 上 & $\begin{array}{l}\text { 發作時 } \\
\text { (稍重) }\end{array}$ \\
\hline 10月 7 日 & 170.94 & 76.77 & 94.17 & 同 & 上 & $\begin{array}{l}\text { 發作時 } \\
\text { (稍輕) }\end{array}$ \\
\hline 10 月 8 日 & 163.40 & 83.25 & 80.15 & 同 & 上. & 空腹時 \\
\hline 10 月 16 日 & 170.50 & 75.76 & 94.74 & $\begin{array}{l}\text { 10月10日 } \\
\text { アスト }\end{array}$ & $\begin{array}{r}\text { 1) } \\
\times \text { VI定 } \\
\end{array}$ & $\begin{array}{l}\text { 發作時 } \\
\text { (重) }\end{array}$ \\
\hline 10 月 20 日 & 145.36 & 73.62 & 71,74 & 同 & 上 & 空腹時 \\
\hline 10 月 29 日 & 150.83 & 73.62 & 77.21 & $\begin{array}{l}10 \text { 同 } \\
1022 \text { 日 } \\
\text { ヒヨレス } \\
\text { オレーブ油 } \\
1 \text { 日 }\end{array}$ & 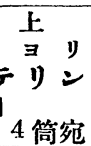 & 空腹時 \\
\hline
\end{tabular}


第五表 青 と $\bigcirc$

\begin{tabular}{|c|c|c|c|c|c|c|}
\hline 日 附 & 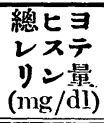 & 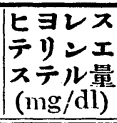 & 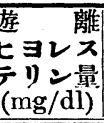 & 治 & 療 & $\begin{array}{l}\text { 發 作 又 } ~ \\
\text { 空腹八時別 }\end{array}$ \\
\hline 10月 6 日 & 183.15 & 107.57 & 75.58 & 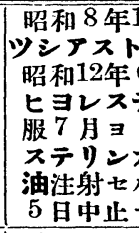 & 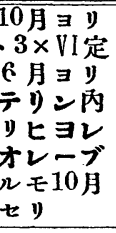 & 空腹時 \\
\hline 10月 7 日 & 183.45 & 111.74 & 71.71 & $\begin{array}{r}\text { ツシアス } \\
\end{array}$ & $\times$ VI 定 & $\begin{array}{l}\text { 發作時 } \\
\text { (稍重) }\end{array}$ \\
\hline 10月13日 & 170.98 & 104.63 & 66.35 & 同 & 上 & $\begin{array}{l}\text { 發作時 } \\
\text { (重.) }\end{array}$ \\
\hline 10月 16 日 & 175.19 & 103.07 & 72.12 & 同 & 上 & 空腹時 \\
\hline 10 月 29 日 & 174.27 & 98.04 & 76.23 & $\begin{array}{c}\text { 同 } \\
10 \text { 月 } 21 \text { 是 } \\
\text { レステリ } \\
\text { ブ油 } 1\end{array}$ & 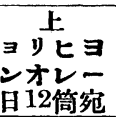 & 空腹時 \\
\hline
\end{tabular}

y. ท

济 昭

オ 和

文古

ブ产十

油 击

$\exists>$ 迄

ス八

日石

三等院

筒

宛 言比

同隽 三

月 注 發

示射 作

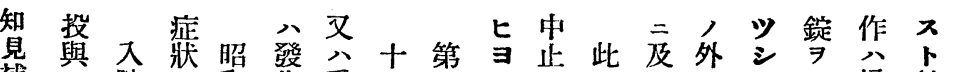

第当止此及外三青公食年强

シ 院 $\exists$ 和作重士五

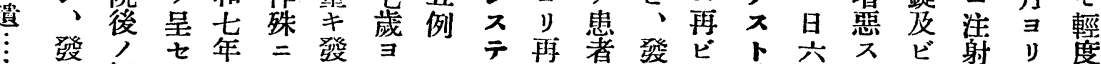

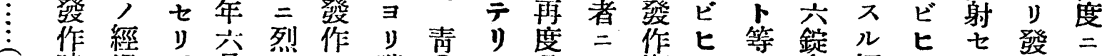

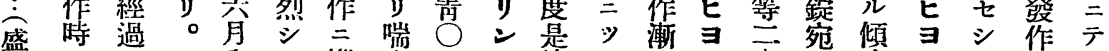

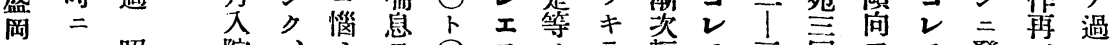

谷照院、录寻 $\bigcirc$ ス

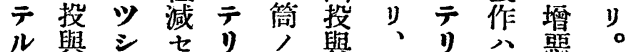

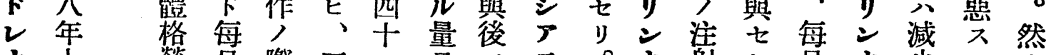

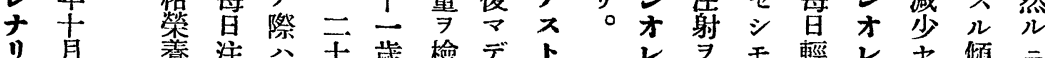

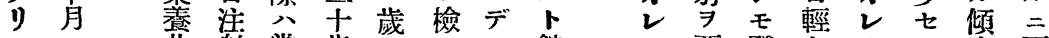

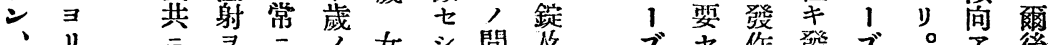

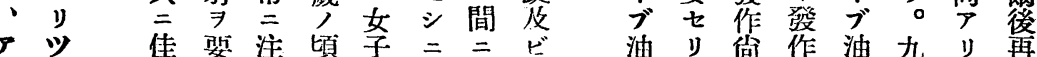

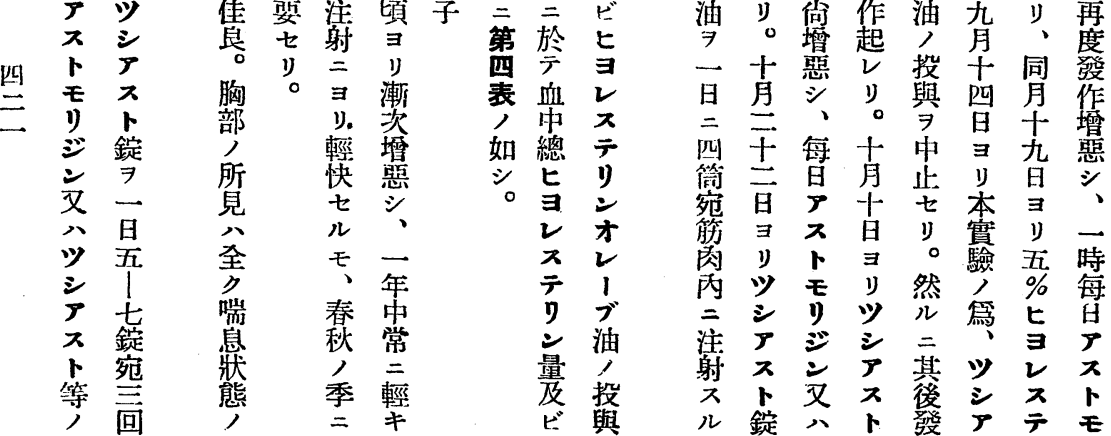


シ 開 治 二

第而始療例血

四 後中 中

例 テ十止第 總

二此 三 時 三 ヒ

於際旦文表

血目心牲

僅中 七 第

二七於寻第 テ

減寻卡四 例

少 ス 治 ス 療テ 量

示テ療 テ 第量

ス リ 歨 投 表

血 - = 與、例

遊 ス 此中第 第

囄 テ 著直 五列

七几 變 後 表

量ナ云第

ス第 济比吾 於

テ 一、这市

》 例

第

量 五

八例

全 二

例 於

於 著

テ 變

減ナ

少キ

モ

示 第

ᄌ

第

兽

例

於

於 ツ 目次

僅 学 少

二 ス ア

增治示

加 銫 療 シ

示 投 與 前

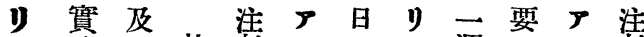

У驗 ビ此射 ス $ヨ$ 週 ス 成七ノセトリオ間ルト 績 $、$ 患 $シ$ 等 $ヒ \boldsymbol{v}$ 持 狀 銫 行 績 者二一ヨ1續態,

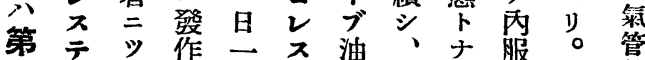
○リキ漸 1 テ 表之テ次三リ一基り拘三喘 汅工昭減筒ン日息 至 ス 和少, 第テ十七皮投筒レ和、ト者 五儿三吾與 $コ$ ス士發錠 吾量年。注 $\ni$ リテ三作, 血 表量十其射中漸》年, 投中

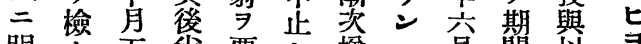
明七五筒要言堛一月間

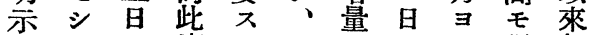
七二七療ルツ文严り强初 ル第 ヨ法二シ テ酉 $ツ$ サ

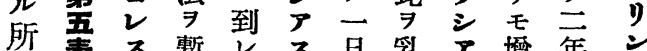

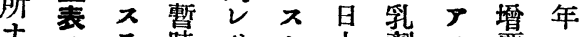
ナノテ時りト十鼎ス惡、量

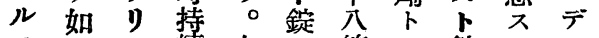

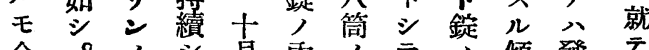

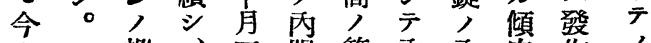

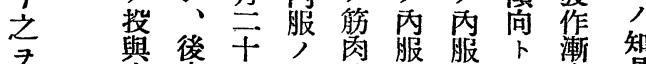

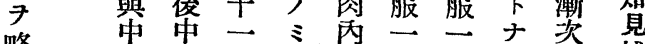
略止止百占注週吕年輕 補

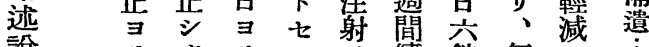
說 リ タ リシ $尹$ 續錠 每 明再儿再二行分宛白來

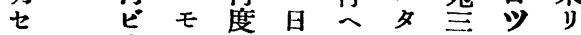
バ之照五 $尹$ リル回シ シ 盛

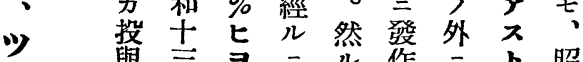

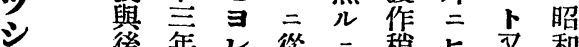
後年

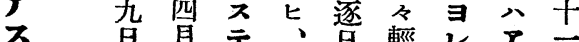
下自当再發減不

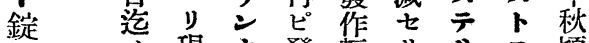
投分現オ發輕りリリモ䪸 與間在レ作減。ン 時云穴

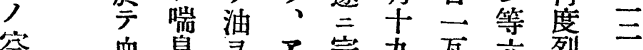
愎 血纂 時總作日下古割十キ

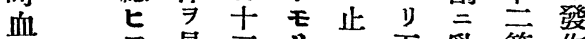

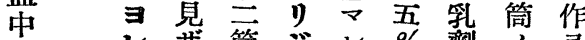
も

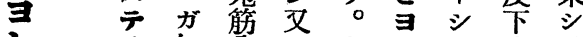
スり如肉分十文注、 テ 量 


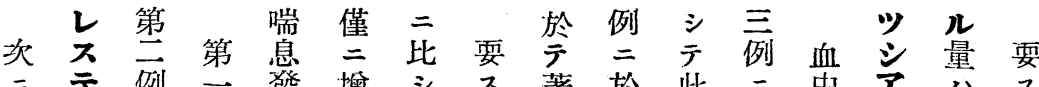
二テ例一發䚍 シ ス著於此二中ア少 ツ $\boldsymbol{y}$ 二例作加著ル變亏際於總 ス多ル 氣ジ於、時, 變二な著血亏卡少二 管

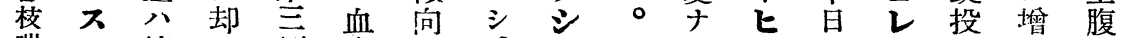
喘、第 $ッ$ 例中

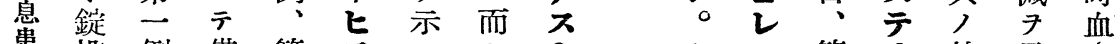

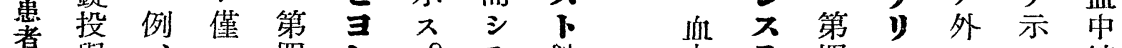

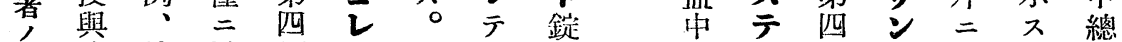

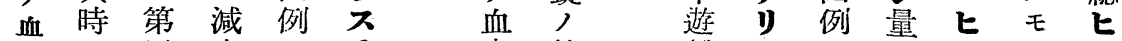

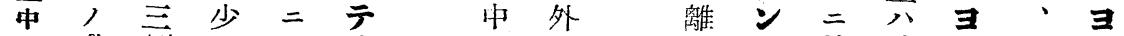
七發例 コ 於 $\boldsymbol{y}$ 七 $\exists$ 作: 示示

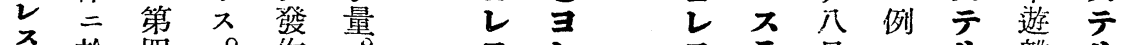

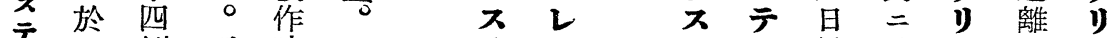

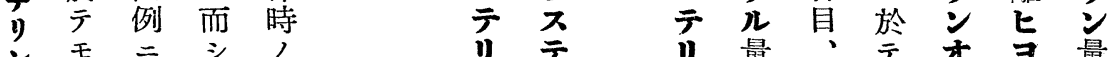
量第 於 テ 血 二 $\rightarrow$ 血 中 就 例 何 中 總 分第王旨旨

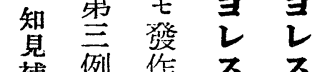
補例作 ス ス 掼、時テ テ 第 僅 リ リ 威四例 增 盛 例增 量

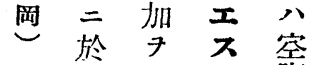
テ 示 テ 腹 何 シ ル 時 ᄂ? 量 モ 第 永 前 毷 $v$ 同例 例 樣 二 二 比 四血於於 三 三虫却蔥蓄 何 七テ无 ヨ減》僅 乙少、 二 ス 衁 譄 テ 示中 加 》 量旨 シ

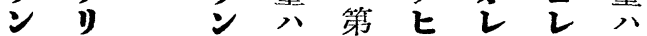
- ン 量 第五 $コ$ I ス エオ⿱一兀㇒例レブテ シ ス 2 第例二 ス 油 リ テ1 - - 於 テ注 ル ブ 例第テ リ 射 量 量注第 $九 \circlearrowright$ 時八鉸 公射例旦才, 僅投 僅時例: 目 ᄂ 空二與 二, 第第何 フ腹減 減血第严何 ブ時少 少總例、壬注中示僅 傾七二第 $ツ$ 射七ス二 向寻於五齐開寻。減 乙 $匚$ 例 ア 始 レ 少 示页何 $=$ ス 後 즈

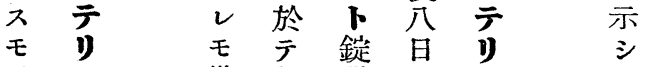
血量 僅何單貝竟自

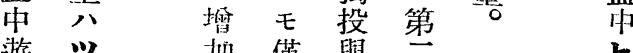
遊 ツ 扣 僅 興 鬲㫐 離 妾 示 減 時 例 当不少比於年 ᄂ ス錠、示著士 リ

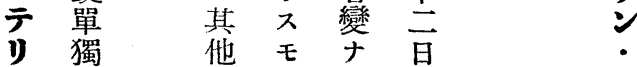

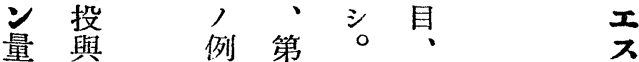
量時與而第面 
第
ア 音
ス

下述

錠 今゙

微 實

量 驗

畑綘

狀 7

腺 總

粉 括

末

含 バ

有左

投 如

與

ヨ

リ

氣

管

校

息

患

空

腹

血

中

總

E

주

줒

J

量

八

僅

二

減

少
リ シ 量 重 要 輕 ッ 页血第 第增

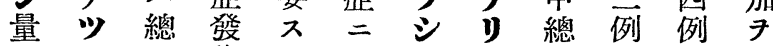

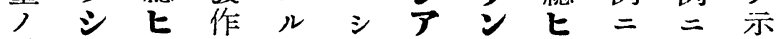
增 $\rightrightarrows コ ニ$ ス 量 $ヨ$ 於於 シ

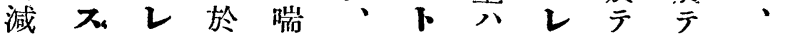
ナ「ステ息血鏰僅 ス 減何第枝 シ 銫テ、發中投二テ少 $v$ 二 喘

第 內 リ減作總與減 $\boldsymbol{7} モ$ 例恩

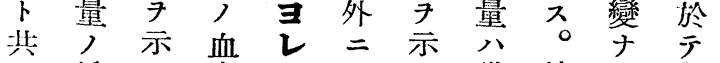
二增 ス中元

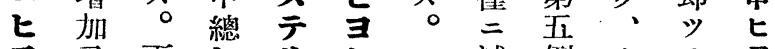
ヨ又而七リと減例血テ蛮 ᄂ 減 テ ᄂ 量 テ ノ ツ 遊少 テ少此 ス リト際テヒヒ向 同血り ヨオ オ ス オジ ンレレ示トレ゙

レク、ヒ量 ス 1、方六 ブ ブ 僅 レ 三リ 油 油三 ス 例ン 注 增 テ 二 ・射 注減 》 於工時 射 $ン$ テ 七示・・テ發 ルス發儿作 時。不量二

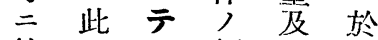
於ノル輕ビテ テ 堨 量 重 遊 係 心二離第 登菖拘七 二 發ツ變 ラ蕬例 作方采尗し

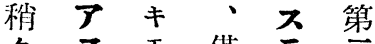
輕页 、集 テ 云 症錠 血增 芩 二投 中 加 量 第 テ 與遊 血 $=\boldsymbol{七}$ シ 減 二 中於寻、筑 七テレ一見テ ヨモ ス 例 ズ發 乙同示, 。作 テ 樣 リ 秒
血與 》 テ 知

中 前 $气$ 血 智

七)量中補

当檢公七遭

乙索第 寻

ス 公的文

テ行例 $ᄌ$ 盛

リ ハ 第 テ 岡

ンザ 第

エ モ 例 レ

ス、第 工

テツ四

几シ 例 テ

量 $\boldsymbol{\gamma}$ ル

八刀些量

著小等量

變 錠 何 第 四

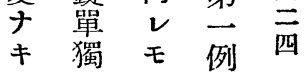

、與 作 第

血 時時 王

遊發篗㐰

離 作 省 第

永 於例
モ投發、 


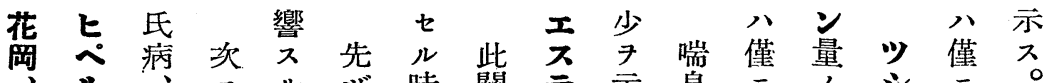

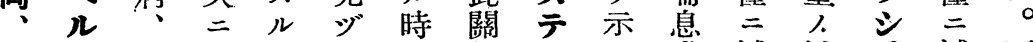

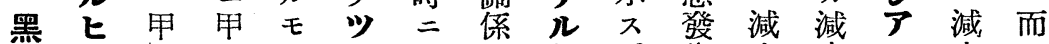

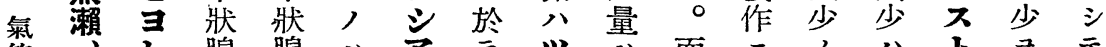
管、乙腺腺

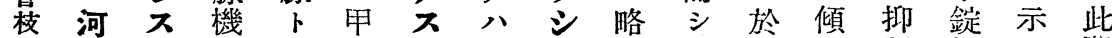
喘野テ能血狀下發 ア々 テ テ向制投 ス 際 息、り京中腺鋜作 ス 一 血 三

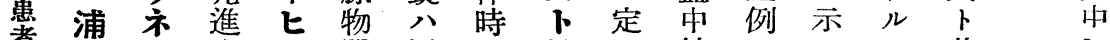

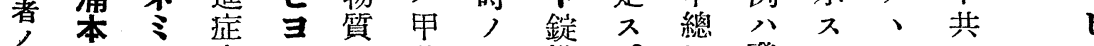

血、了患レナ狀血投

中栃八者 スリ腺 中 與

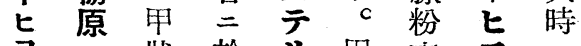

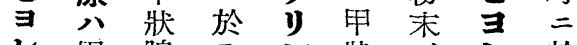

乙甲腺 $\bar{v}$ 狀、方

テ 狀劑 ハ量腺ハ

り腺ノヒト粉パテ无

? 剔投采, 禾べリ略

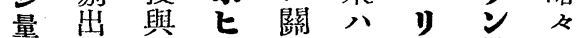

$=ニ=\exists$ 係ツ $ン$ 量同

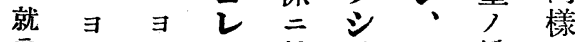

テリリス就 アエ 㙫

知血抑 テ テ ス フ 減 シ

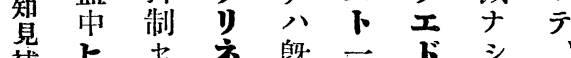

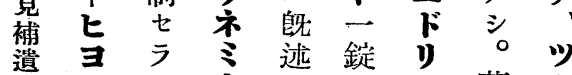

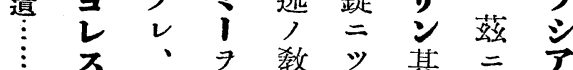
盛テ牛空丮他之基

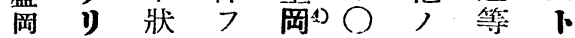

บ腺卜田 $\dot{\bigcirc}$ 混了鉟

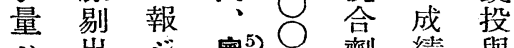
八出 溪 ${ }^{5}$ 四 劑 䋶 與

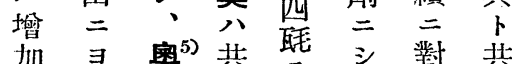

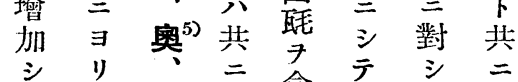
、增 三s的含 此考 ヒ

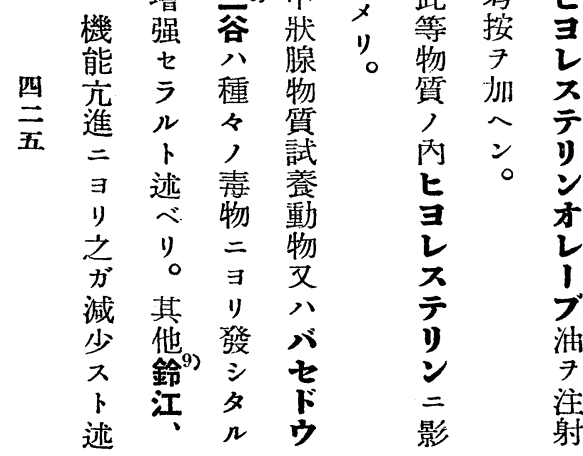
寻發 モ モ 乙血此蛮不 ス輕中ノレ゙ テ重 遊際 ス リ $\boldsymbol{y}$ 二 離 血 テ 拘七中 y 量 $ヨ$ 總 ン エ フズレヒオ オ 增、ス ヨレテ 減血 テレ I ル 血總 ソ テ 油 白 中七量り $リ$ 多 遊录少 離已僅 量射尛 七 ス 光 七 影 ヨテ增 鈤 バ 響 レリ加加、

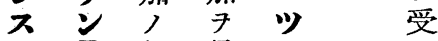
テ 量 傾 見シ ケ りノ向䒔采ル

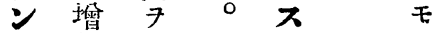
量加示而政略 檑 示 減 シ 血 獨 定 二、虫投产

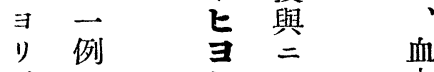
血秒 ス 中 ₹ テ 血. 七重 離 ヨ症總寻 レ發 ス 作 中 テ 二 I $\exists$ ᄂ リ於 テ ス $\overline{7}$ ンテ ル テ 量 リ

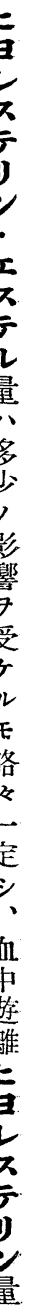




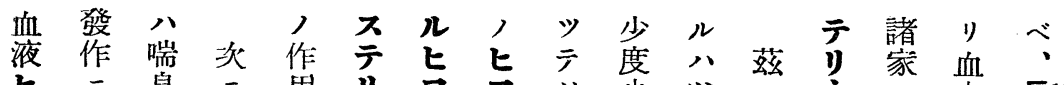

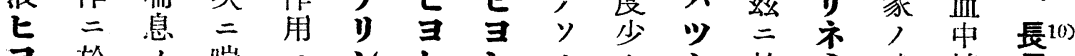

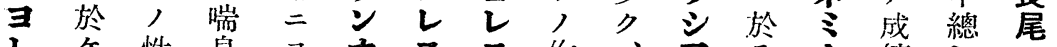

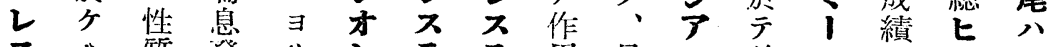

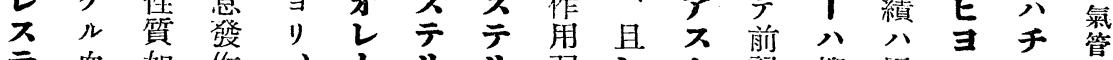

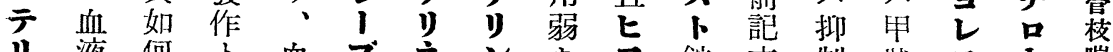

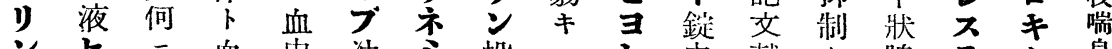

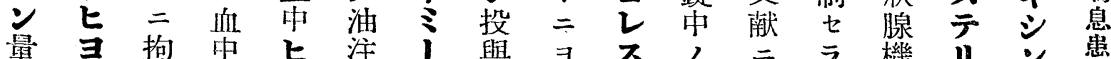

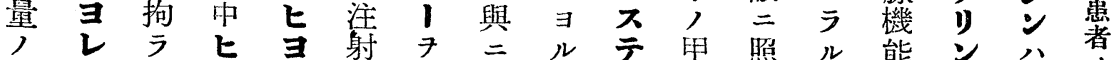

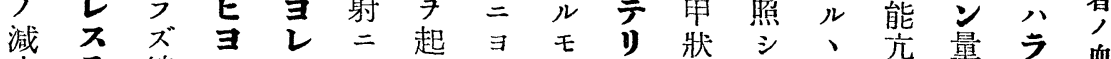

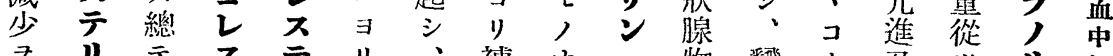

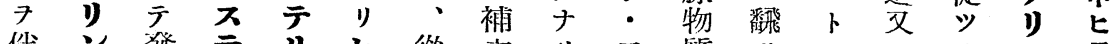

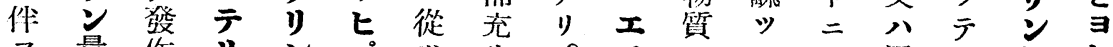
フ量作 リ

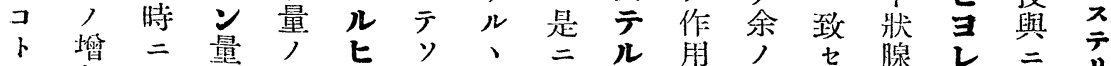

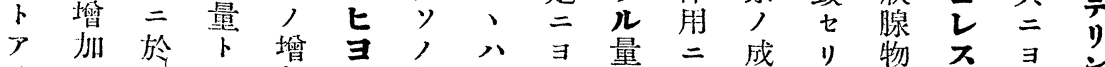
リ八テ, 加し中當

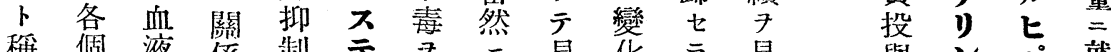
稱 個液係制テ $テ ニ$ 見化

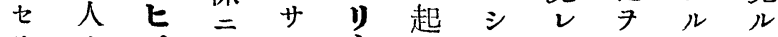

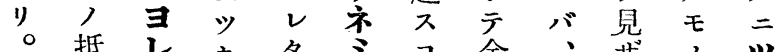
向抵 こ

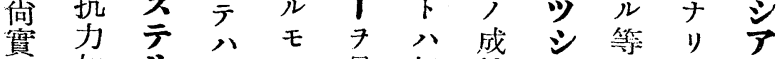
驗如り既, 見既績 $\vec{\jmath}$ 八。 的何

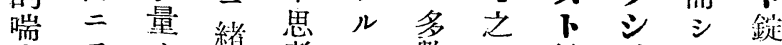

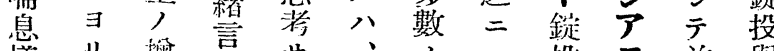

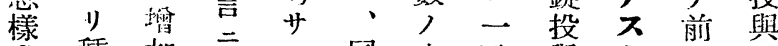

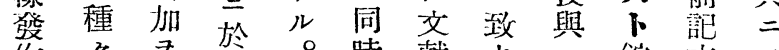

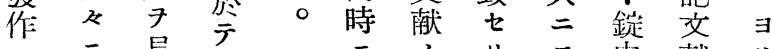

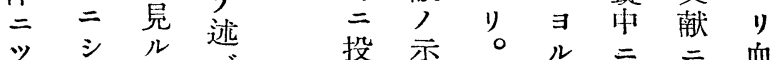
\% シ ル 投示。ル 二 血 キ テ、趣タ 與 不然血含比中

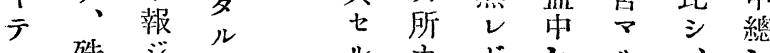
見殊 ジ如当ドル、七 ル重之りツリさモコ、血寻

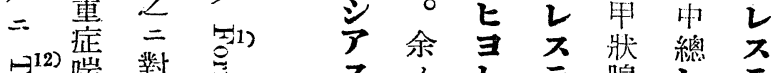

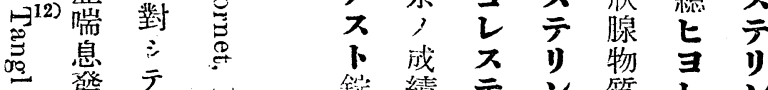

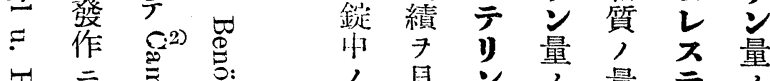

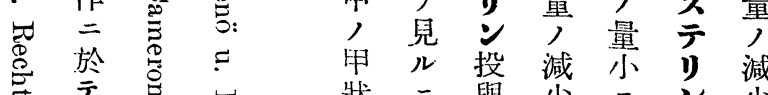
管总平丑投減尔り減 飴却

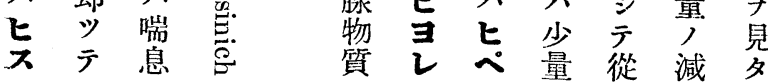

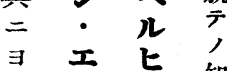
寻至旨智 血原鼠 中不遗 七及元 $\exists$ ビ 遊栾盛 万離 令 凮 页旨単 L抑

量 $\therefore \pi$ 減 少 尖量整

且 $=$ 竹11) 四

叠減枆突

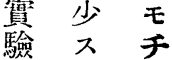
的 $\mathrm{k}$ 七報 F 唬 刍”。撗 


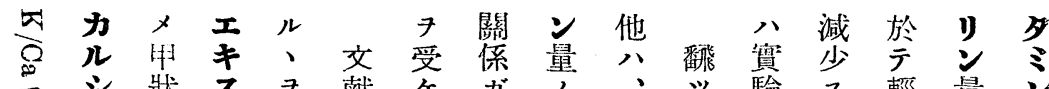
系䇂狀 ス

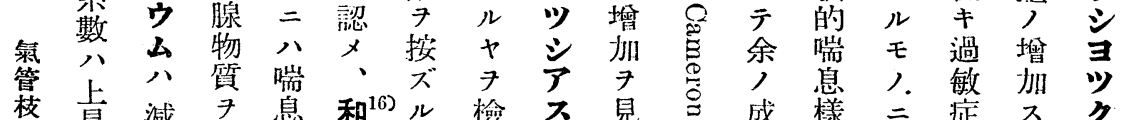
喘昇減陚臬梨 ${ }^{10}$ 檢

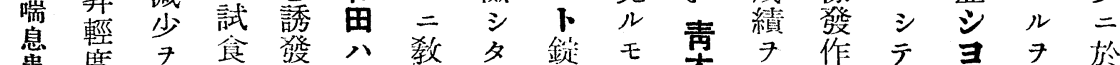
患度

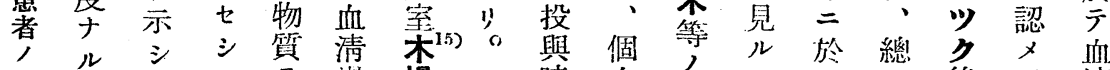

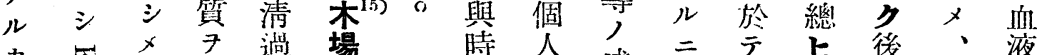
血力

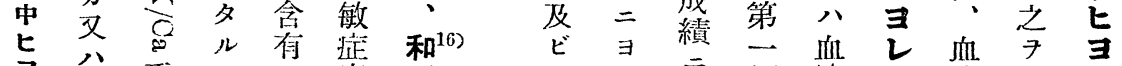

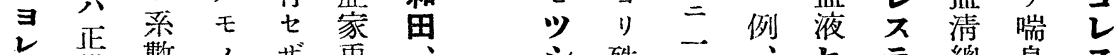
ス 常稘人

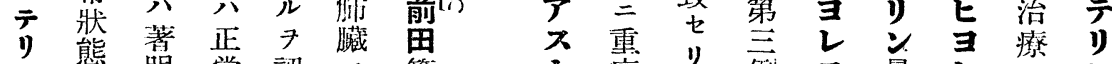
ン 態明 常 認 エ 等症。例 ス 量レニン 量

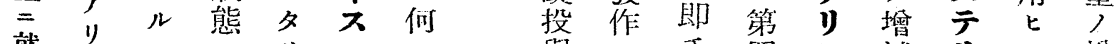
就卜 上 上 , 報昇 ア

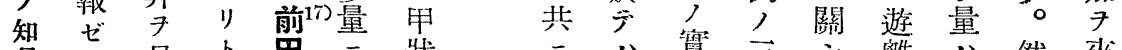

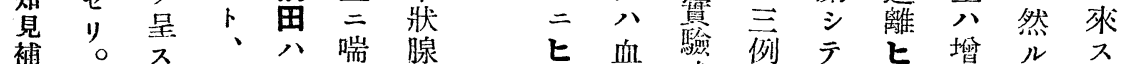

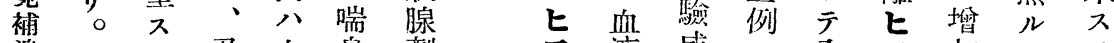
遗以モ 及血息劑

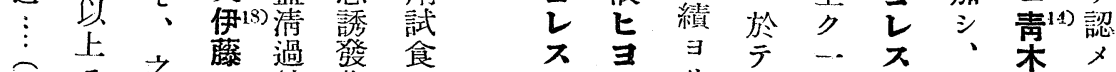

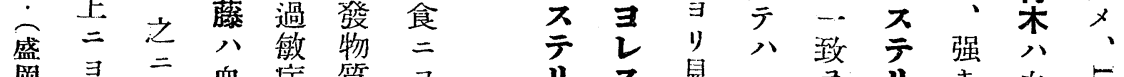

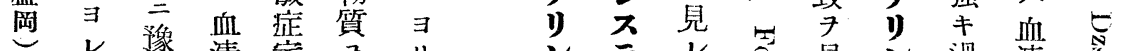

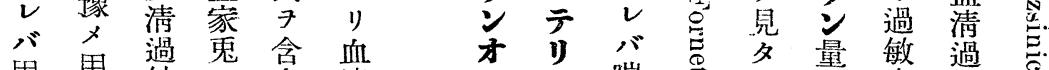

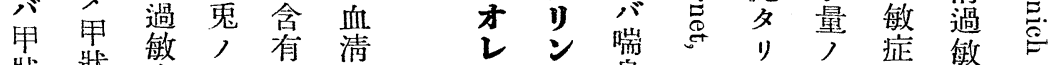

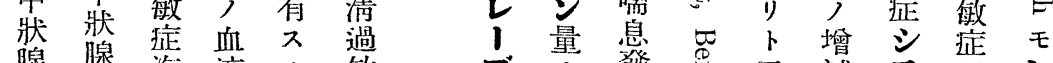

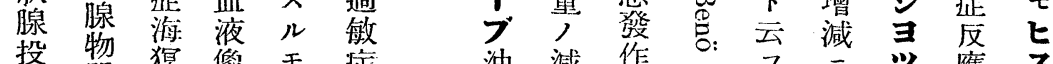

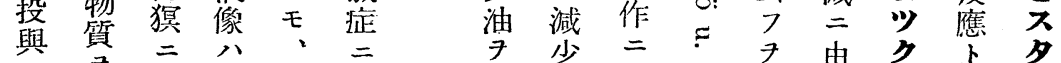

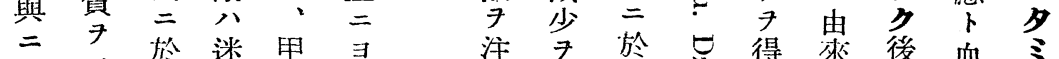

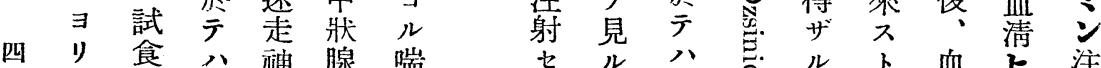
二 血 七 血 經 試 息

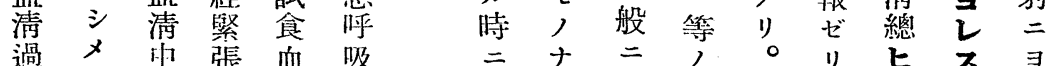

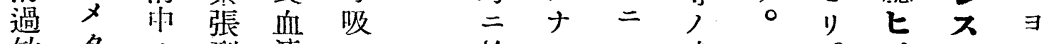
敏タ, 型清ノ於り血成当デ 症ルカ

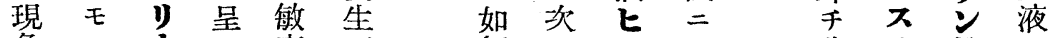
象ノウ ス 症 ガ 何

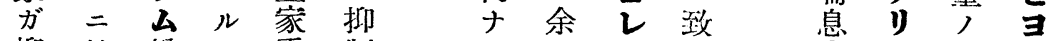

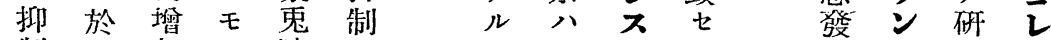
制テ加、遮七影コテ作量究 ス セ 心 シ 豫臟 ラ 響, リ モ 
余

迁

內

科

院

些

管

枝

喘

意

患

者

空

腹

時

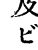

發

作

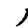

IIII

E

는

국

)

量

及

ボ

ス

甲

永

ス

F

微

量

甲

爿

腺

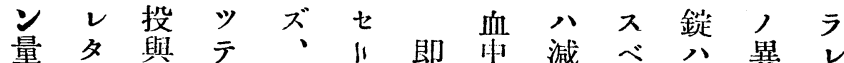

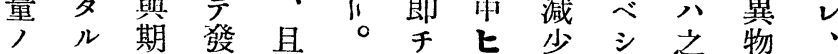
增モ間作要前前度卜方清從 減ノ略時余前者し八考投掃 テニ々ノノ者つス治人與機テ管 來 シ 倍 血 實 サテ加中驗於シ リ 前ル 於芹清喘

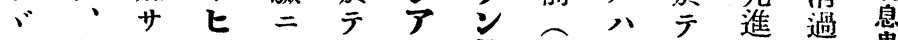
第 モ

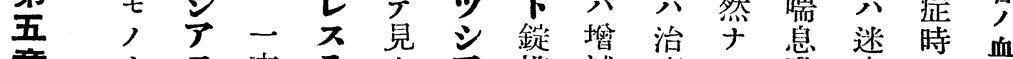
章ナス方テタア投娍療り發走省中

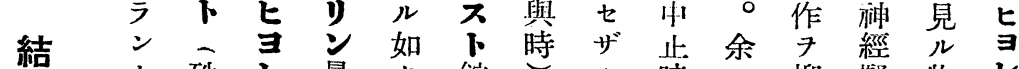
力殊乙量り、鋜しル時了抑緊物レ

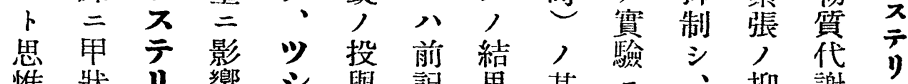
惟狀り 響 シ 與記果其二、・抑謝?

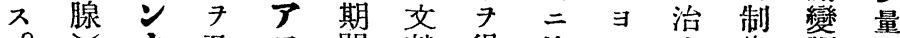

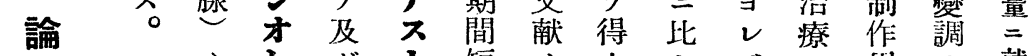
フレボト短ノタジ ニ用ノ就 作、サ錠ク成り差ツ見二發六

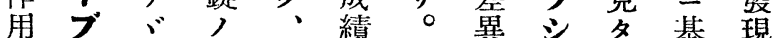
十油ル血甲 平 分注モ中狀反認 万墢モ亦 二射, 七腺シ メ 卜 作, 抑遦

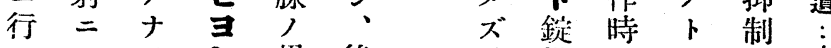

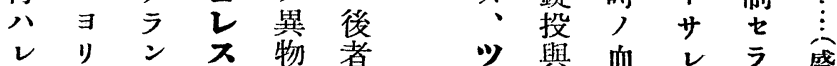
發、カ 作 ツ。掃

輕 刘後減角 方 減 ス 者少及 ス シ $\boldsymbol{1}$ 二作 $\boldsymbol{1}$ 血於用迷鋜

比少相市

テ ヨ 前 件 經 ヨ 發り者七ノ 作 ス 、緊 ス 時テ比 喘 張 テ ノ 》 シ 息抑 血り 、發 制 ソ 中減 ツ 作 作 投 七少 $シ$ 輕 用 與 ヨ作 子減十時 乙用

元防占莎行 テ 止鉸從
○, 七り、当

万發录。王

下作落,

鉭二

- 於 テ 於 如

七テ リ テ シ

血 $ソ$ 甲

乙中量狀而

ス七, 腺 シ

テ 垍物 テ 四

リ ᄂ 減 質 迁3

投 テ 何 含 譽

與り 等 有 敎 時 $ン$ 力授 量ノルハ 發㢳影 ツ之 作增 響 シ 二加 $ァ$ 甲 於度及不
シ與 血 レ ラ 盛 


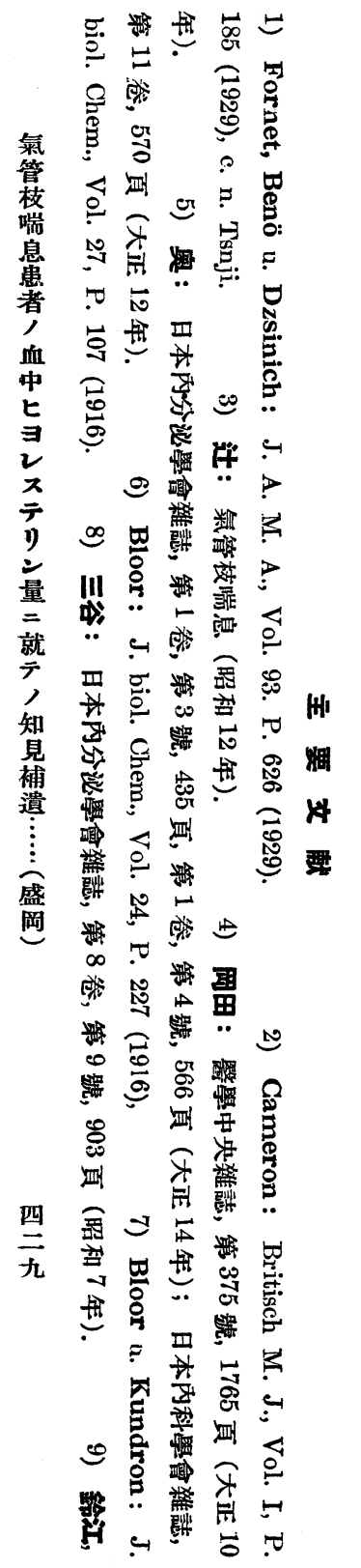

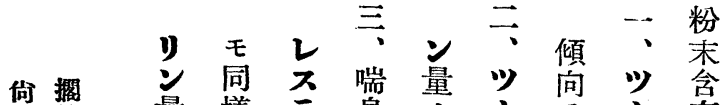

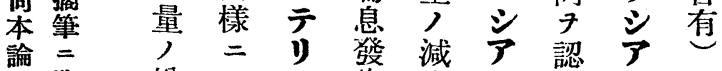
交臨增 シ学作少 ス㕕

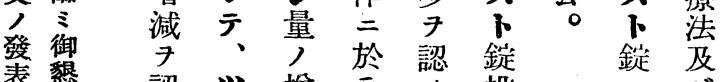

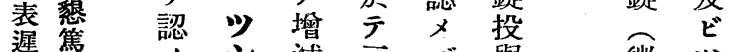

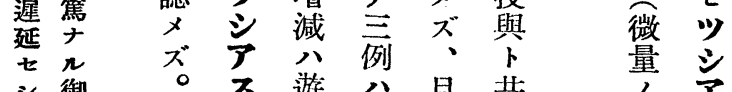
蓹。遊八具共分了 著檤 者 應 御 召 閱 出

征笋 篇賜 煘晹 n 離血文二 銑 與 ᄂ $乞$ ᄂ 粉 卜ス寻不年 共 テ シ テ テ

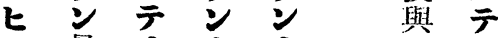
ヨ量り才オ $才$ オ

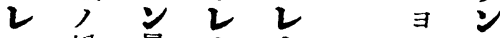
万賭量 111 療 テ減 ブ ブ 氣法 》二增油油管, 由 加單 7 枝影 才來 ヨ獨注喘響 乙 1 ル $ル$ 射 ブモモニバ 者セ 油, ‘ ヨ、一ルシ 空 㴬 如例血㝊腹次 七。却 總 $\boldsymbol{r}$ 血 結 ルコツ七錠虫果 時ノテ寻單總 7 二閵減乙獨得 於係少 不投当多

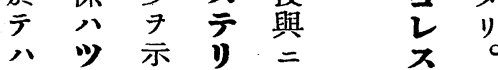
發音石寻 作 時不發增血量 血䤫 時 加總 公 中投 $フ 7$ 七 僅 旨 與 血 認 寻減 レ二總ズ ス 少 テ 於 


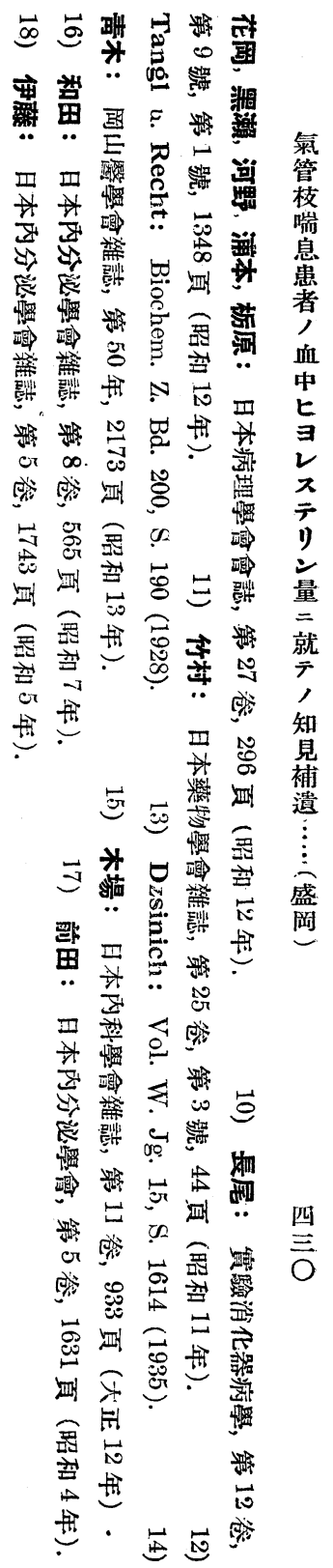




\title{
Ein Beitrag zur Frage der Cholesterinämie beim Bronchialasthma.
}

\author{
Von
}

\author{
Dr. K. Morioka
}

(Aus der I. Med. Krinik der Kaiserl. Universität zu Kyoto in Japan.

Exvorstand: Prof. Dr. K. Tsuji, Vorstand: Prof. Dr. K. Inoue)

Der Verfasser hat den Blutcholesteringehalt der Kranken mit Bronchialasthma festgestellt und entsprechende Versuche angestellt. Als Kranke wurden 5 Asthmaleidende zur Untersuchung herangezogen. Der Blutcholesteringèhalt wurde in der Nüchternzeit und auch während des Asthmaanfalles geprüft. Zugleich wurde versucht, festzustellen, wie das Asthmamittel Tsussiast (enthält eine kleine Menge Thyreoideasubstanz) und ferner eine kombinierte Therapie mit Tsussiast plus Cholesterin den Blutcholesterinspiegel der Asthmakranken beeinflussen. Die Untersuchungsergebnisse lassen sich wie folgt zusammenfassen :

1) Bei fortgesetzter peroraler Darreichung der TsussiastTabletten (enthält eine kleine Menge Thyreoideasubstanz) zeigte der gesamte Blutcholesterinspiegel der Asthmakranken eine Tendenz, sich ein wenig zu verringern.

2) Bei der kombinierten Darreichung der Tsussiast-Tabletten mit intramuskulärer Injektion der Cholesterin-Olivenölemulsion wurde weder die in 1) erwähnte Tendenz zur Hypocholesterinämie noch eine Hypercholesterinämie, welch letztere bei der Cholesterindarreichung zu erwarten ist, beobachtet. Es wurde also bei dieser kombinierten Therapie keine nennenswerte Veränderung des Blutcholesterinspiegels festgestellt.

3) Der gesamte Cholesterinspiegel während der Anfallszeit des Bronchialasthmas war bei 3 Fällen unter fünfen vermehrt, aber bei einem Falle war er vermindert. Aus den fraktionierten Messungsergebnissen des Blutcholesterins war zu entnehmen, dass diese Hyperoder Hypocholesterinämie in der Anfallszeit mit der Zu-oder Abnahme 
des freien Blutcholesterins parallel gehen. Dieser Parallelismus zwischen dem gesamten Blntcholesterin und dem freien Blutcholesterin besteht auch bei peroraler Darreichung der Tsussiast-Tabletten.

(Autoreferat)

\section{Über den Einfluss der Iontophorese mittels Fluorwasserstoffsäurelösung auf die Basedow'sche Krankheit. (I. Mitteilung.) \\ Grundversuche über die Giftigkeit der Fluorwasserstoffsäurelösung.}

Von

Dr. K. Shimizı

(Aus der I. Med. Klinik der Kaiserl. Universität zu Osaka in Japan. Direktor : Prof. Dr. N. Fuse)

Die Tatsache, dass Fluor von kleinem Atomgewichte und dabei von grosser Osmose ist, veranlasste die Verfasser zu Versuchen hinsichtlich der Anwendung von Fluorwașserstoffsäurelösung zur Iontophorese bei der Basedow'schen Krankheit, weil der Widerstand gegen elektrischen Strom, wie allgemein anerkannt, bei Fällen Basedow'scher Krankheit verringert wird.

Über die Giftigkeit der Fluorwasserstoffsïurelösung führten wir folgende Grundversuche aus :

A) Toxizitätsversuche mit Fluorwasserstoffsäurelösungen von verschiedenen Konzentrationen bei ORYZIAS LALIPES (einem Fisch Medaka)

B) Hämolytische Wirkung dieser Lösung auf Menschenblut.

C) Einfluss dieser Lösung auf Sauerstoff bedürfnis der Taubenblutkörperchen.

Die drei genannten Versuche führten zu folgenden Schlüssen: 